\title{
DERECHOS HUMANOS Y MIGRACIONES: PARADOJAS Y REFORMULACIONES EN 2017
}

\author{
Human Rights and migration: Paradoxes and reformulations in 2017
}

\author{
Julieta MORALES SÁNCHEZ
}

\begin{abstract}
Sumario:
I. El nuevo concepto de soberanía estatal ante el derecho internacional de los derechos humanos y la migración II. Nacionalidad y migración: ¿límites a la dignidad humana? III. ¿Ciudadanía migrante?: relación entre derecho y derechos IV. El discurso de odio: actualización y ejecución V. Derechos humanos, minorías e igualdad VI. Dignidad e igualdad frente a las minorías VII. Derecho a la igualdad y no discriminación VIII. Fuentes
\end{abstract}

\begin{abstract}
Resumen: La protección de los derechos humanos supera al concepto de soberanía estatal, el límite real a la soberanía de los Estados lo impone la dignidad del ser humano, la distinción que el Estado hace sobre quien es un nacional y quien es extranjero, se convierte en un criterio de desigualdad surgiendo una condición de vulnerabilidad de los migrantes. En las sociedades democráticas, es preciso erradicar la discriminación y recordar que el principio de igualdad constituye una norma imperativa de derecho internacional que debe ser cumplida por todos los países, por ello se propone superar el debate en torno al término minoría para centrarse en el pleno respeto y garantía de los derechos de todas las personas que -regular o irregularmente- se encuentran en el territorio de un Estado.
\end{abstract}

Palabras clave: Derechos humanos, soberanía, migración, ciudadanía, discriminación, minorías, igualdad

Abstract: The Human Rights protection go beyond the concept of sovereignty, the real limit to this, is imposed by the dignity of human beings, the distinction that the State makes over who is a national and who is a foreigner, that becomes an inequality criteria, creating a condition of vulnerability on migrants. In democratic societies, it is necessary to eradicate discrimination and reforce that the principle of equality is an imperative norm of international law that must be fulfiled by all countries, in consecuence, it is proposed to overcome the debate on the term "minority" in order to focus on the total respect and guarantee of every person's rights, who-regular or irregularly-are in a certain territory.

Keywords: Human rights, sobereignity, migration, citizenship, discrimination, minorities, equality

* Doctora en Derecho por la UNAM y Doctora en Derecho Constitucional por la Universidad de Castilla- La Mancha (España). Investigadora Nacional nivel I del Sistema Nacional de Investigadores de CONACYT. Directora General del Centro Nacional de Derechos Humanos de la Comisión Nacional de los Derechos Humanos (CNDH). Profesora de la Facultad de Derecho de la UNAM. 


\section{El nuevo concepto de soberanía estatal ante el derecho internacional de los derechos humanos y la migración}

En algunos sectores se plantea la confrontación entre soberanía y migración irregular y con dicho argumento se pretenden legitimar violaciones a derechos humanos de migrantes. Sin duda, este es un falso dilema como muchos otros que se han producido ${ }^{1}$.

Bustamante sostiene que no hay soberanía que valga para justificar la violación sistemática de los derechos humanos ${ }^{2}$. Sin embargo, es necesario hacer una precisión: no es la soberanía en sí la que violenta los derechos humanos de migrantes, sino las políticas implementadas por los Estados bajo el argumento de defensa a su soberanía. Existe, sostiene el mismo autor, una contradicción dialéctica entre dos ejercicios de soberanía por la cual se da un conflicto entre el derecho soberano de un Estado a controlar sus fronteras - y decidir su política de migracióny la obligación de respetar los derechos humanos contraída internacionalmente mediante la ratificación de tratados, obligación adquirida también en ejercicio de su soberanía ${ }^{3}$.

Bodino define a la soberanía como el poder absoluto y perpetuo de una República ${ }^{4}$. Este concepto ha sido analizado, deconstruido y reconstruido por múltiples autores. Sin embargo, lo que interesa para efectos de este trabajo es abordar someramente los nuevos significados de la palabra soberanía. Zagrebelsky sostiene que, con la transición del Estado de derecho al Estado constitucional, la soberanía se ha transformado debido a la actuación de fuerzas corrosivas internas y externas, como son: el pluralismo político y social, la formación de centros de poder alternativos y concurrentes al Estado, la institucionalización supraestatal y la atribución de derechos a las personas que pueden hacer exigibles y justiciables ante jurisdicciones internacionales demandando a los Estados por su actuación u omisión en perjuicio de dichos derechos 5 . Por lo tanto la soberanía ya no puede visualizarse como un poder absoluto ni perpetuo de los Estados, que puede ir en contra -incluso- de las personas sujetas a su jurisdicción.

Así, la comunidad internacional de los Estados posee un fragmento amplio de soberanía en materia de los derechos humanos [...] y [...] debe de estar dispuesta a asumir la protección de esas libertades y esos derechos ahi donde fracasa el Estado constitucional nacional ${ }^{6}$; por lo que la comunidad de naciones se convierte en titular de decisiones parcialmente soberanas al servicio del ser humano ${ }^{7}$. Kotzur afirma que solamente una concepción instrumental de la soberanía al servicio del ser humano, puede justificar cualquier forma de ejercicio del poder ${ }^{8}$. Esto debe

1 Otro de los falsos dilemas que se manejan en la actualidad es el de seguridad pública vs. derechos humanos.

${ }^{2}$ Vid Bustamante, Jorge (2002), Migración internacional y derechos humanos, UNAM, Instituto de Investigaciones Jurídicas, México, p. 166.

3 Existe una paradoja en esta contradicción: un Estado tiene el derecho soberano de limitar su propia soberanía. Véase Bustamante, Jorge, "La paradoja de la autolimitación de la soberanía: derechos humanos y migraciones internacionales, pp. 123-156 en: Prevensión de la violencia a grupos vulnerables y los derechos humanos. Los derechos de los migrantes, fasículo 5, Comisión Nacional de Derechos Humanos, [en línea], disponible en: https:// archivos.juridicas.unam. $m x / w w w / b j v / l i b r o s / 1 / 342 / 8 . p d f$.

${ }^{4}$ Bodino, Jean (1973), Los seis libros de la república, trad. Pedro Bravo, Aguilar, Madrid, p. 46.

5 Zagrebelsky, Gustavo (2007), El derecho dúctil. Ley, derechos y justicia, $7^{\mathrm{a}}$. ed. trad. de Marina Gascón, Trotta, Madrid, pp. 10-14.

${ }^{6}$ Kotzur, Markus (2003), "La soberanía hoy. Palabras clave para un diálogo europeo-latinoamericano sobre un atributo de Estado constitucional moderno", en: Häberle, Peter y Kotzur, Markus, De la soberanía al derecho constitucional común: palabras clave para un diálogo europeo-latinoamericano, trad. Héctor Fix-Fierro, UNAM, México, p. 106.

7 Ibídem, p. 107.

${ }^{8}$ Ibídem, p. 111.

CIENCIA JuRÍDICA. Departamento de Derecho. División de Derecho, Política y Gobierno, Universidad de Guanajuato - Año 6, No. 11, 2017 
de llevar a reflexionar sobre los tipos de soberanía que existe actualmente en cada uno de los países.

Carrillo Salcedo observa, en este mundo interconectado lleno de relativas soberanías, que la relevancia del Estado sigue siendo indiscutible en la protección de los derechos humanos, incluso en esta época de transición en la que las estructuras tradicionales se encuentran en crisis [...] $]^{9}$. Los Estados tienen un papel primordial en la protección de los derechos humanos (muestra de ello es el carácter complementario y subsidiario del sistema internacional de protección de derechos humanos) pero ya no se puede visualizar al Estado como ese ente omnipotente capaz de imponer su voluntad sin seguir ninguna directriz y sin tener ningún límite. Hoy los Estados tienen que cumplir sus compromisos internacionales y respetar las normas de jus cogens de derechos humanos.

Así, el límite real a la soberanía de los Estados y a la actuación estatal, lo impone la dignidad del ser humano.

Por tanto, un Estado puede establecer su política migratoria, regular sus fronteras, exigir una serie de requisitos para el cruce de fronteras y permanencia en su territorio pero lo que no puede hacer es violentar los derechos humanos en sus políticas, acciones públicas, legislación ni decisiones.

Además de ello, es cuestionable el hecho de exigir un trámite administrativo - que en ocasiones puede ser discrecional- para la concesión de un cúmulo suplementario de derechos ya que ello se erige como una restricción ilegítima a la dignidad humana.

\section{Nacionalidad y migración: ¿límites a la dignidad humana?}

Generalmente los ordenamientos domésticos diferencian entre nacionales y extranjeros. Jorge Bustamante observa que la distinción que el Estado hace sobre quien es un nacional y quien es extranjero, se convierte en un criterio de desigualdad entre nacionales y extranjeros que se ve sancionado por el Estado al dar un trato desigual a nacionales y extranjeros, equivalente a un acceso diferencial a los recursos públicos que favorece al nacional. De lo anterior surge una

9 Carrillo SAlcedo, Juan Antonio (1969), Soberanía del Estado y derecho internacional, Tecnos, Madrid, 1969, p. 48. En este sentido, también véase del mismo autor (2001), Soberanía de los Estados y Derechos Humanos en Derecho Internacional Contemporáneo, $2^{\text {a }}$ ed. Tecnos, Madrid, pp. 107-139. 
condición de vulnerabilidad ${ }^{10}$ de los migrantes, que los hace susceptibles de violaciones a sus derechos humanos en el país receptor.

Así, la nacionalidad ${ }^{11}$ se ha convertido en una institución de exclusión ${ }^{12}$ y discriminación, ya que es un requisito indispensable para que las personas puedan gozar y ejercer sus derechos.

Los derechos derivan de la dignidad humana, lamentablemente están siendo supeditados, en su goce y ejercicio, a una nacionalidad. Por lo que aquellas personas que están imposibilitadas para adquirir la nacionalidad del Estado en el que residen - legal o ilegalmente- no tienen la posibilidad de reclamar el goce y ejercicio de sus derechos.

Claramente lo que necesitan las personas es gozar de sus derechos como seres humanos, no como ciudadanos de un país ${ }^{13}$. Supeditar el goce y ejercicio de los derechos humanos a una nacionalidad o ciudadanía, constituye una restricción a la dignidad humana. Sin pretender caer aquí en una petición de principio, es válido afirmar que si los derechos humanos tienen su origen en la dignidad que cada persona posee, los Estados están obligados a garantizar dichos derechos. Claramente esos derechos pueden ser restringidos legalmente pero no suspendidos de manera arbitraria o discrecional y, más aún, el Estado debe diseñar mecanismos para prevenir y sancionar la violación a los derechos humanos de cualquier persona sujeta a su jurisdicción. Cualquier acción u omisión del Estado en este sentido atenta contra la dignidad humana. Así, todas las personas poseen la misma dignidad por el sólo hecho de ser humanos. La dignidad no está condicionada por un trámite administrativo, ni por un documento, ni por una calidad migratoria. En consecuencia, todo Estado tiene la obligación de garantizar, a cualquier persona que se encuentre en su territorio, el goce y ejercicio de sus derechos.

Aunque la Corte IDH ha reconocido que la nacionalidad es un prerrequisito para el ejercicio de determinados derechos, también sostiene el carácter imperativo del principio de protección igualitaria y efectiva de la ley y del principio de no discriminación ${ }^{14}$.

Por otro lado, los Estados también tienen la obligación de proteger a sus nacionales en cualquier parte en la que se encuentren; a este respecto la Corte IDH ha expresado: el derecho a

\footnotetext{
${ }^{10}$ Bustamante define a la vulnerabilidad estructural como la condición de impotencia que se deriva de una asimetría de poder frente a otros que es sancionada por el Estado. Y habla también de la vulnerabilidad cultural que se integra por el conjunto de valores, ideas, prejuicios, ideologías, xenofobias y racismos que se van generando en la sociedad huésped acerca de los extranjeros-inmigrantes, que retroalimentan la vulnerabilidad estructural. Cfr. Bustamante, Jorge (2003), op. cit. nota 2, p. 29.

${ }^{11}$ Ibarra Palafox sostiene que es la ciudadanía la que se configura como una institución de exclusión, sin embargo, en este estudio, se entiende que para el caso de México y la mayoría de países latinoamericanos la nacionalidad comprende a la ciudadanía (es decir, todos los ciudadanos son nacionales, pero no todos los nacionales son ciudadanos; además de que la principal exigencia de los migrantes se refiere fundamentalmente al goce y ejercicio de sus derechos civiles, los cuales son otorgados a todos los nacionales aunque no sean ciudadanos). Se entiende que la postura adoptada por Ibarra Palafox es consecuencia de que la diferenciación entre ciudadanía y nacionalidad no existe en algunos países (como EUA o países europeos, en donde sólo se habla de ciudadanía). Por lo anterior, si la presente tesis es leída por una persona en cuya tradición jurídica no exista la diferenciación antes mencionada, la expresión correcta es: la ciudadanía se ha convertido en una institución de exclusión. Cfr. Ibarra Palafox, Francisco (2005), Minorías etnoculturales y Estado nacional, UNAM, México, pp. 164 y 188.

${ }^{12}$ Carbonell afirma que con base en la ciudadanía se siguen manteniendo inaceptables discriminaciones y desigualdades basadas en un accidente tan coyuntural como puede ser el lugar de nacimiento. Cfr. CARBONELL, Miguel (2006), “¿Se justifican las fronteras en el siglo XXI?”, en: Este país. Tendencias y opiniones, número 189, diciembre, p. 5 .

${ }^{13}$ García Quiñones, Rolando y Montes Rodríguez, Norma (2002), "La migración internacional en el nuevo escenario. El dilema de las fronteras", en: Revista de la Universidad de la Habana, 254/255, segundo semestre 2001-primer semestre, La Habana, p. 197.

${ }^{14}$ La Corte IDH [...] entiende que la nacionalidad es la expresión jurídica de un hecho social de conexión de un individuo con un Estado [...] (párrafo 136). La importancia de la nacionalidad reside en que ella, como vínculo 
tener una nacionalidad significa dotar al individuo de un mínimo de amparo jurídico en las relaciones internacionales, al establecer a través de su nacionalidad su vinculación con un Estado determinado [...] (por lo que) se hace acreedor a su protección diplomática ${ }^{15}$. Algunos Estados han eludido esta obligación.

\section{III. ¿Ciudadanía?: Relación entre derecho y derechos}

Frente a la migración se replantea el papel del Derecho. En algunos contextos el Derecho limita o restringe a la migración; en otros, la penaliza; en algunos más, pretende regularla. Pero también debería reflexionarse qué sucede en aquellos puntos geográficos donde impera la anomia, entendiendo por ésta a la inobservancia de normas jurídicas, morales y sociales, según Santiago $\mathrm{Nino}^{16}$.

Ahora bien, qué papel desempeña el Derecho frente a los derechos de las personas migrantes.

Danilo Zolo afirma que la contestación en forma de expulsiones y persecuciones, o a través de la negación de la calidad de sujetos a los inmigrantes, por parte de las ciudadanías amenazadas por la presión migratoria, está escribiendo y parece destinada a escribir en los próximos decenios las páginas más luctuosas de la historia civil y política de los países occidentales ${ }^{17}$.

Javier de Lucas señala que la dicotomía ciudadano/extranjero se asienta sobre dos supuestos: la construcción del Estado nacional y la homogeneidad social derivada de la coyuntural (esporádica y aún limitada en el tiempo) presencia del extranjero en la composición social. Hoy ninguno de esos dos supuestos se mantiene incólume ${ }^{18}$.

En sentido parecido, Michelangelo Bovero afirma que

Los derechos de ciudadanía política, los derechos de participación [...] deben ser considerados derechos de la persona, es decir, corresponden (o deberían corresponder) a todo individuo en tanto que es persona, en la medida en la cual la persona está sometida a esas discusiones políticas: y no hay ninguna razón válida para excluir a alguno de aquellos que están sometidos

jurídico político que liga una persona a un Estado determinado, permite que el individuo adquiera y ejerza los derechos y responsabilidades propias de la pertenencia a una comunidad política. Como tal, la nacionalidad es un prerrequisito para el ejercicio de determinados derechos (párrafo 137) [...] La Corte considera que el principio de derecho imperativo de protección igualitaria y efectiva de la ley y no discriminación determina que los Estados, al regular los mecanismos de otorgamiento de la nacionalidad, deben abstenerse de producir regulaciones discriminatorias o que tengan efectos discriminatorios en los diferentes grupos de una población al momento de ejercer sus derechos. Además, los Estados deben combatir las prácticas discriminatorias en todos sus niveles, en especial en los órganos públicos, y finalmente debe adoptar las medidas afirmativas necesarias para asegurar una efectiva igualdad ante la ley de todas las personas (párrafo 141). Corte Interamericana de Derechos Humanos, Caso de las niñas Yean y Bosico, sentencia de 8 de septiembre de 2005, párrafos supra señalados. Se regresará a este caso posteriormente.

${ }^{15}$ Opinión Consultiva OC-4/84 Propuesta de modificación a la Constitución Política de Costa Rica relacionada con la naturalización, 19 de enero de 1984, párrs. 34 y 35.

${ }^{16}$ Nino, Carlos Santiago (1992), Un país al margen de la ley. Estudio de la anomia como componente del subdesarrollo argentino, Buenos Aires, Emecé, p. 19. También $c f r$. Merton, Robert (1964), Teoría y estructura sociales, Fondo de Cultura Económica, México, y Zovatto, Daniel, et. al. (2005), Argentina: Una sociedad anómica. Encuesta de cultura constitucional, UNAM, Asociación Argentina de Derecho constitucional, Idea Internacional, México, p. 8.

${ }^{17}$ Zolo, Danilo (1999), "La strategiadellacittadinanza", en: Zolo, Danilo (ed.), La Cittadinanza. Appartenenza, identitádiritti, 2a . Ed. Roma-Bari, Laterza, p. 42; CARbonell, Miguel (2009), Dilemas de la democracia constitucional, Porrúa, Cámara de Diputados, Comisión Estatal de Derechos Humanos de Aguascalientes, México, pp. 64 y 65.

${ }^{18}$ De LuCAs, Javier (1994), El desafío de las fronteras. Derechos humanos y xenofobia frente a una sociedad plural, Temas de Hoy, Madrid, p. 135; y Carbonell, Miguel, Dilemas [...], op. cit. nota 17, p. 65. 
(de manera estable) a un ordenamiento normativo del derecho de participar en la formación de ese mismo ordenamiento ${ }^{19}$.

Sin embargo, la realidad es compleja y debemos de plantear una opción que pueda -al menos- dar directrices frente a la problemática que representa el ejercicio de los derechos humanos y las restricciones que introduce la ciudadanía a los derechos. Como señala Müller, la construcción de las normas jurídicas dentro de las tensas relaciones que guardan entre sí el Derecho y la realidad, en un campo de "reales y normativos", ha sido examinada hasta ahora como una cuestión propia de la filosofía del Derecho. La relación entre Derecho y realidad se muestra entonces como una necesidad para comprender la correlatividad entre normatividad y facticidad ${ }^{20}$.

No se profundizará en estos aspectos pero se abre la discusión para el análisis del lector

\section{El Discurso de odio: actualización y ejecución}

En 1965, la Convención Internacional sobre la Eliminación de Todas las Formas de Discriminación Racial, expresó la condena de los Estados parte a toda la propaganda y todas las organizaciones que se inspiren en ideas o teorías basadas en la superioridad de una raza o de un grupo de personas de un determinado color u origen étnico, o que pretendan justificar o promover el odio racial y la discriminación racial, cualquiera que sea su forma, y el compromiso de aquéllos a tomar medidas inmediatas y positivas destinadas a eliminar toda incitación a tal discriminación o actos de tal discriminación, entre ellas:

Declarar como acto punible conforme a la ley toda difusión de ideas basadas en la superioridad o en el odio racial, toda incitación a la discriminación racial, así como todo acto de violencia o toda incitación a cometer tales actos contra cualquier raza o grupo de personas de otro color u origen étnico, y toda asistencia a las actividades racistas, incluida su financiación;

Declarar ilegales y prohibir las organizaciones, así como las actividades organizadas de propaganda y toda otra actividad de propaganda, que promuevan la discriminación racial e inciten a ella, y reconocer que la participación en tales organizaciones o en tales actividades constituye un delito penado por la ley;

No permitir que las autoridades ni las instituciones públicas nacionales o locales promuevan la discriminación racial o inciten a ella.

En lo dispuesto en este instrumento internacional, se identifican el elemento básico de lo que ahora se conoce como discurso de odio: la incitación a cometer actos de discriminación o de violencia.

En similar sentido, el Pacto Internacional de Derechos Civiles y Políticos (1966) incorporó la prohibición de toda apología del odio nacional, racial o religioso que constituya incitación a la discriminación, la hostilidad o la violencia.

De manera reciente, en 2013, el Comité para la Eliminación de la Discriminación Racial, encargado de la supervisión e interpretación de la Convención, apuntó que el término discurso de odio racista es aquél dirigido contra los grupos reconocidos por el artículo 1 de ésta, es decir,

[...] los pueblos indígenas, los grupos cuya condición se basa en consideraciones de ascendencia, y los inmigrantes o los no ciudadanos, incluidos los trabajadores domésticos migrantes, los refugiados y los solicitantes de asilo, así como el discurso dirigido contra las mujeres

\footnotetext{
${ }^{19}$ Bovero, Michelangelo (2002), "Ciudadanía y derechos fundamentales”, en: Boletín Mexicano de Derecho Comparado, núm. 103, enero-abril, p. 24; Carbonell, Miguel, Dilemas... op. cit. nota 17 p. 67.

${ }^{20}$ Caballero, Ángel (2005), Constitución y realidad constitucional, Porrúa, Tecnológico de Monterrey, México, p. 37. 
pertenecientes a esos y a otros grupos vulnerables, así como contra las personas pertenecientes a determinados grupos étnicos que profesan o practican una religión distinta de la mayoría, por ejemplo las expresiones de islamofobia, antisemitismo y otras manifestaciones de odio similares contra grupos etnorreligiosos, así como las manifestaciones extremas de odio tales como la incitación al genocidio y al terrorismo ${ }^{21}$.

El Comité también expuso que el discurso de odio racista puede adoptar múltiples formas y no está limitado a las expresiones de carácter explícitamente racial [...] el discurso en que se ataca a grupos raciales o étnicos concretos puede emplear un lenguaje indirecto para disimular sus metas y objetivos ${ }^{22}$. Esto es, el discurso de odio racista no necesita ser explícito, puede realizarse mediante ataques a determinados grupos utilizando una argumentación distinta a la racial o matizando su contenido o sus fines, como sucede en el caso de los grupos migratorios indocumentados o irregulares.

De manera concreta, el Comité señaló que los Estados parte deben declarar como actos punibles y castigar:

Toda difusión de ideas basadas en la superioridad o en el odio racial o étnico, por cualquier medio;

La incitación al odio, el desprecio o la discriminación contra los miembros de un grupo por motivos de su raza, color, linaje, u origen nacional o étnico;

Las amenazas o la incitación a la violencia contra personas o grupos por los motivos señalados en el apartado b) anterior;

La expresión de insultos, burlas o calumnias a personas o grupos, o la justificación del odio, el desprecio o la discriminación por los motivos señalados en el apartado b) anterior, cuando constituyan claramente incitación al odio o a la discriminación

a) La participación en organizaciones y actividades que promuevan e inciten a la discriminación racial ${ }^{23}$.

Para calificar los actos de difusión e incitación como actos punibles conforme a la ley, el Comité consideró que deben tenerse en cuenta los siguientes factores contextuales:

El contenido y la forma del discurso: si el discurso es o no provocativo y directo, la forma en que está construido y es difundido y el estilo en que se expresa.

El clima económico, social y político que prevalecía en el momento en que se formuló y difundió el discurso, incluida la existencia de pautas de discriminación contra grupos étnicos $y$ otros grupos, como los pueblos indígenas. Los discursos que resultan inocuos o neutrales en un contexto pueden adquirir connotaciones peligrosas en otro: en sus indicadores sobre el genocidio, el Comité puso de relieve la importancia de las condiciones locales al valorar la significación y los posibles efectos del discurso de odio racista.

La posición o condición del emisor del discurso en la sociedad y el público al que se dirige el discurso. El Comité ha señalado repetidamente la influencia de los politicos y otros formadores de opinión pública en la creación de un clima negativo respecto de los grupos protegidos

${ }^{21}$ Comité para la Eliminación de la Discriminación Racial, Observación general No. 35 (CERD/C/GC/35), párr. 6, [en linea], disponible en: http://tbinternet.ohchr.org/_layouts/treatybodyexternal/Download.aspx?symbolno=CE $R D \% 2 f C \% 2 f G C \% 2 f 35 \&$ Lang=en.

${ }^{22}$ Ibídem, párr. 7.

${ }^{23}$ Ibídem, párr. 13. 
por la Convención, y ha alentado a esas personas y entidades a adoptar actitudes positivas encaminadas a promover la comprensión y la armonía entre las culturas. El Comité es consciente de la especial importancia de la libertad de expresión en los asuntos políticos, y también de que su ejercicio entraña deberes y responsabilidades especiales.

El alcance del discurso, con inclusión del tipo de audiencia y los medios de transmisión: si el discurso se difundió o no en medios de comunicación generales o en Internet y la frecuencia y amplitud de la comunicación, en particular cuando la repetición sugiere la existencia de una estrategia deliberada para suscitar hostilidad hacia grupos étnicos y raciales.

Los objetivos del discurso: el discurso encaminado a proteger o defender los derechos humanos de personas y grupos no debe ser objeto de sanciones penales o de otro tipo ${ }^{24}$.

Por su parte, en el ámbito interamericano, el párrafo 5 del artículo 13 de la Convención Americana sobre Derechos Humanos (1969) establece que: Estará prohibida por la ley [...] toda apología del odio nacional, racial o religioso que constituyan incitaciones a la violencia o cualquier otra acción ilegal similar contra cualquier persona o grupo de personas, por ningún motivo, inclusive los de raza, color, religión, idioma u origen nacional.

La Comisión Interamericana de Derechos Humanos ha señalado —en relación con el párrafo quinto del artículo 13 de la Convención Americana- que los Estados deben adoptar legislación para sancionar la apología del odio que constituya incitación a la violencia o cualquier otra acción ilegal similar ${ }^{25}$.

El Plan de Acción Rabat sobre la prohibición de la apología del odio nacional, racial o religioso que constituya incitación a la discriminación, hostilidad o violencia (2012), señala que los Estados deben distinguir claramente entre: (i) las expresiones que constituyan un delito, (ii) las expresiones que no son sancionables penalmente pero que podrían justificar un proceso civil o sanciones administrativas, y (iii) las expresiones que no son legalmente sancionables pero que aún generan preocupación en términos de la tolerancia, el civismo y el respeto de los derechos de los demás ${ }^{26}$.

En el sistema europeo, la Recomendación No. R (97) 20 emitida por el Comité de Ministros del Consejo de Europa, definió al discurso de odio como

[...] todas las formas de expresión que difundan, inciten, promuevan o justifiquen el odio racial, la xenofobia, el antisemitismo y cualquier otra forma de odio fundado en la intolerancia, incluida la intolerancia que se exprese en forma de negacionismo agresivo y etnocentrismo, la discriminación y hostilidad contra las minorías, los inmigrantes y las personas nacidas de la inmigración $n^{27}$.

La Decisión Marco 2008/913/JAI del Consejo de Europa estableció la obligación de cada Estado miembro de adoptar,

\footnotetext{
${ }^{24}$ Ibídem, párr. 15 .

${ }^{25} \mathrm{CIDH}$. Informe Anual 2009. Informe Anual de la Relatoría Especial para la Libertad de Expresión. Capítulo II (Marco Jurídico Interamericano sobre el Derecho a la Libertad de Expresión). OEA/Ser.L/V/II. Doc. 51. 30 de diciembre de 2009, párr. 58.

${ }^{26}$ Rabat Plan of Action on the prohibition of advocacy of national, racial or religious hatred that constitutes incitement to discrimination, hostility or violence. Conclusions and recommendations emanating from the four regional expert workshops organized by OHCHR in 2011, and adopted by experts at the meeting in Rabat, Marruecos, 5 de octubre de 2012, parr. 20. Para su consulta [en linea], disponible en: http://www.ohchr.org/Documents/HRBodies/HRCouncil/RegularSession/Session22/A-HRC-22-17-Add4_sp.pdf.

${ }^{27}$ [En linea], disponible en: https://rm.coe.int/CoERMPublicCommonSearchServices/DisplayDCTMContent?docu mentId $=0900001680505 d 5$.
} 
[...] las medidas necesarias para garantizar que se castiguen las siguientes conductas intencionadas:

la incitación pública a la violencia o al odio dirigidos contra un grupo de personas o un miembro de tal grupo, definido en relación con la raza, el color, la religión, la ascendencia o el origen nacional o étnico;

la comisión de uno de los actos a que se refiere la letra a) mediante la difusión o reparto de escritos, imágenes u otros materiales;

la apología pública, la negación o la trivialización flagrante de los crímenes de genocidio, crímenes contra la humanidad y crímenes de guerra tal como se definen en los artículos 6, 7 y 8 del Estatuto de Roma, dirigida contra un grupo de personas o un miembro de tal grupo definido en relación con la raza, el color, la religión, la ascendencia o el origen nacional o étnico cuando las conductas puedan incitar a la violencia o al odio contra tal grupo un miembro del mismo;

a) la apología pública, la negación o la trivialización flagrante de los crímenes del Estatuto del Tribunal Militar Internacional adjunto al Acuerdo de Londres, de 8 de agosto de 1945, dirigida contra un grupo de personas o un miembro de tal grupo definido en relación con la raza, el color, la religión, la ascendencia o el origen nacional o étnico cuando las conductas puedan incitar a la violencia o al odio contra tal grupo un miembro del mismo ${ }^{28}$.

El Tribunal Europeo de Derechos Humanos ha señalado que [...] es necesario, en las sociedades democráticas, sancionar e incluso prevenir todas las formas de expresión que propaguen, inciten, promuevan o justifiquen el odio basado en la intolerancia ${ }^{29}$.

$\mathrm{Y}$, acerca del concepto de discurso de odio, el mencionado Tribunal lo ha conceptuado como todas aquellas formas de expresión que propaguen, inciten, promueva o justifiquen el odio basado en la intolerancia (incluida la intolerancia religiosa) ${ }^{30}$.

Respecto a estas formas de expresión que constituyen un discurso de odio ha indicado que estas manifestaciones [...] no se benefician de la protección del artículo 10 del Convenio ${ }^{31}$. El referido artículo reconoce y protege el derecho a la libertad de expresión.

Es fundamental no perder de vista estos elementos cuando hablamos de personas migrantes que se encuentran expuestas a reacciones públicas de xenofobia y discriminación por parte de las autoridades, que desconocen sus obligaciones internacionales o convencionales y aquellas derivadas del jus cogens. Es preciso recordar que el principio de igualdad y no discriminación constituye una norma de jus cogens y como norma imperativa de derecho internacional debe ser cumplida por todos los países, independientemente de la ratificación o no de un tratado internacional.

Es preciso mencionar que el discurso de odio vinculado a la migración, produce una reflexión del nosotros que pretende fundamentar la exclusión de los otros. De manera similar a lo que ocurre entre las culturas diferenciadas, se construyen estereotipos que aspiran a definir a los

\footnotetext{
${ }^{28}$ Decisión marco 2008/913/JAI del Consejo de Europa, emitida el 28 de noviembre de 2008, [en línea], disponible en: http://eur-lex.europa.eu/legal-content/ES/TXT/?uri=URISERV\%3Al33178.

29 Recomendación 1805 (2007) de la Asamblea Parlamentaria del Consejo de Europa sobre Blasfemia, insultos religiosos y discursos de odio contra personas por causa de su religión, [en línea], disponible en: $h t t p: / / w w w$. assembly.coe.int/nw/xml/XRef/Xref-XML2HTML-en.asp?fileid=17569\&lang=en.

30 Asunto Féret c. Bélgica (nº 15615/o7), de 16 de julio de 2009.

${ }^{31}$ Asunto Müslüm Gündüzc. Turquía (nº35071/97).
} 
del otro lado de la frontera y se exacerban esas características con base en el discurso, acciones u omisiones estatales que criminalizan de facto a la migración.

En México, la Suprema Corte de Justicia de la Nación ha sostenido que:

[...] los discursos del odio son aquellos que incitan a la violencia -física, verbal, psicológica, entre otras - contra los ciudadanos en general, o contra determinados grupos caracterizados por rasgos dominantes históricos, sociológicos, étnicos o religiosos. Tales discursos se caracterizan por expresar una concepción mediante la cual se tiene el deliberado ánimo de menospreciar y discriminar a personas o grupos por razón de cualquier condición o circunstancia personal, étnica o social. La problemática social en relación con los discursos del odio, radica en que mediante las expresiones de menosprecio e insulto que contienen, los mismos generan sentimientos sociales de hostilidad contra personas o grupos. Así, la diferencia entre las expresiones en las que se manifieste un rechazo hacia ciertas personas o grupos y los discursos del odio, consiste en que mientras las primeras pueden resultar contrarias a las creencias y posturas mayoritarias, generando incluso molestia o inconformidad en torno a su contenido, su finalidad se agota en la simple fijación de una postura, mientras que los segundos se encuentran encaminados a un fin práctico, consistente en generar un clima de hostilidad que a su vez puede concretarse en acciones de violencia en todas sus manifestaciones. En consecuencia, los discursos del odio van más allá de la mera expresión de una idea o una opinión y, por el contrario, resultan una acción expresiva finalista que genera un clima de discriminación y violencia hacia las víctimas entre el público receptor, creando espacios de impunidad para las conductas violentas ${ }^{32}$.

\section{Derechos humanos, minorías e igualdad}

La Declaración sobre derechos de las personas pertenecientes a minorías nacionales o étnicas, religiosas y lingüísticas determina que las personas pertenecientes a minorías nacionales o étnicas, religiosas y lingüísticas [...] tendrán derecho a disfrutar de su propia cultura, a profesar y practicar su propia religión, y a utilizar su propio idioma, en privado y en público, libremente y sin injerencia ni discriminación de ningún tipo $o^{33}$.

En la actualidad la idea de sociedades nacionales homogéneas no sólo es cuestionable -en múltiples casos- sino sociológica y jurídicamente insostenible.

Por ello, el liberalismo entiende que los Estados existen no sólo para proteger iguales derechos y oportunidades para las personas, sino también para garantizar un marco cultural que permita a éstos ser libres e iguales. La tesis de Kymlicka y Straehle, es que si una cultura des-

\footnotetext{
${ }^{32}$ Rubro: Libertad de Expresión. Actualización, características y alcances de los discursos del odio. Amparo directo en revisión 2806/2012. Enrique Núñez Quiroz. 6 de marzo de 2013. Mayoría de tres votos. Disidentes: José Ramón Cossío Díaz y Alfredo Gutiérrez Ortiz Mena, quienes reservaron su derecho a formular voto particular. Ponente: Arturo Zaldívar Lelo de Larrea. Secretario: Javier Mijangos y González. [subrayado añadido].

${ }^{33}$ Aprobada por la Asamblea General de la ONU en su resolución 47/135 del 18 de diciembre de 1992. Claramente existen conceptos más restrictivos. A manera de ejemplo, se ha dicho, que la expresión minoría nacional se refiere a una proporción más o menos considerable de los "ciudadanos" de un Estado que son de una nacionalidad diferente de la de la mayoría. DeAzcárate, Pablo (1998), Minorías nacionales y derechos humanos, Universidad Carlos III de Madrid, Congreso de los Diputados, Madrid, p. 119.
} 
aparece o es discriminada, las posibilidades de sus miembros de disfrutar de una vida plena se ven dramáticamente rebajadas ${ }^{34}$.

En los Estados plurinacionales, se debe garantizar un marco jurídico adecuado que permita gozar y ejercer plenamente los derechos para las diferentes minorías nacionales (étnicas y culturales) $)^{35}$.

La efectiva vigencia de los derechos de las minorías, en el caso de migrantes indocumentados, plantea ciertas dificultades y controversias; incluso es cuestionable su propia categorización como minoría.

El artículo 27 del Pacto Internacional de Derechos Civiles y Políticos literalmente prevé: En los Estados en que existan minorías étnicas, religiosas o lingüísticas, no se negará a las personas que pertenezcan a dichas minorías el derecho que les corresponde, en común con los demás miembros de su grupo, a tener su propia vida cultural, a profesar y practicar su propia religión y a emplear su propio idioma.

En la literatura se ha comentado las dificultades para coincidir en una definición, incluso se ha aconsejado el sustituir el término minoría por el de grupos nacionales, étnicos, religiosos, culturales, lingüísticos y tribales. Pero inclusive esta detallada descripción excluiría categorías tales como los trabajadores migrantes y las poblaciones indígenas, a menos que estas últimas se consideren idénticas a grupos tribales. Esto, por supuesto, se relaciona con la complicada cuestión de quién decide cuándo estamos frente a una minoría y cuándo no.

Incluso podríamos pensar en el artículo $6^{\circ}$ del Estatuto de Roma que determina se entenderá por "genocidio" cualquiera de los actos mencionados a continuación, perpetrados con la intención de destruir total o parcialmente a un grupo nacional, étnico, racial o religioso. Así, podríamos preguntar si un conjunto de migrantes se configura como un grupo étnico para efectos internacionales.

La Convención Internacional sobre la Eliminación de todas las Formas de Discriminación Racial que ha sido ratificado, por ejemplo, por los EUA, dispone en su artículo 2.1.

Los Estados partes condenan la discriminación racial y se comprometen a seguir, por todos los medios apropiados y sin dilaciones, una política encaminada a eliminar la discriminación racial en todas sus formas y a promover el entendimiento entre todas las razas, y con tal objeto: a) Cada Estado parte se compromete a no incurrir en ningún acto o práctica de discriminación racial contra personas, grupos de personas o instituciones y a velar por que todas las autoridades públicas e instituciones públicas, nacionales y locales, actúen en conformidad con esta obligación.

Si entendemos que existen grupos de personas migrantes indocumentadas que son identificadas por sus características físicas específicas -además de que comparten una misma lengua, cultura y creencia religiosa, por ejemplo- y ello las diferencian del conjunto de población nacional del país de residencia en donde se encuentran entonces la caracterización de grupo es claramente aplicable.

El principio VII del Acta final de la Conferencia sobre la Seguridad y la Cooperación en Europa establece: Los Estados participantes en cuyo territorio existan minorías nacionales respetarán el derecho de los individuos pertenecientes a tales minorías a la igualdad ante la ley, les

\footnotetext{
${ }^{34}$ Kymlicka, Will y Straehle, Christine (2003), Cosmopolismo, Estado-nación y nacionalismo de las minorías. Un análisis crítico de la literatura reciente, UNAM, México, pp. 64 y ss.

${ }^{35}$ En el contexto de entornos culturales y sobre los derechos humanos en el Islam, véase DonNELLY, Jack (1998), Derechos humanos universales en teoría y en la práctica, Gernika, México, pp. 81-10o.
} 
proporcionarán la plena oportunidad para el goce real de los derechos humanos y las libertades fundamentales $y$, de esta manera, protegerán los legítimos intereses de aquéllos en esta esfera.

Para ello resulta importante iniciar haciendo alusión a la opinión emitida el 31 de julio de 1930 por la Corte Permanente de Justicia Internacional, sobre la interpretación del término comunidad, contenido en el Convenio de 27 de noviembre de 1919 entre Grecia y Bulgaria, relativo a la emigración voluntaria de las poblaciones greco-búlgaras. En dicha opinión, la Corte expresó que por comunidad debe entenderse:

un grupo de personas en determinado país o localidad, que poseen una raza, religión, lengua $y$ tradiciones propias y unidos por esta identidad de raza, religión, lengua y tradiciones en un sentimiento de solidaridad, con vistas a preservar sus tradiciones, manteniendo su forma de culto, asegurando la instrucción y educación de sus hijos de acuerdo con el espíritu y tradiciones de su raza y prestándose mutua asistencia.

Otro esfuerzo de definición desde el punto de vista legal se deriva de la interpretación del término minorías étnicas, religiosas o lingüísticas realizada por el Comité de Derechos Humanos de Naciones Unidas en la Observación General No. 23 sobre el artículo 27 del Pacto Internacional de Derechos Civiles y Políticos de 1966.

Según dicha observación, por minoría se debe entender aquel grupo de personas que comparten en común una cultura, una religión o un idioma. De tal propuesta de definición se puede observar que sólo incluye un elemento, al hacer mención de la presencia de caracteres comunes (lengua, religión y tradiciones). Por otro lado, dicha definición deja claro que no es necesario el requisito de la ciudadanía para delimitar - complementar- el término minoría.

En algunos espacios se ha dicho que el concepto de minoría es contextual, que se redefine con el paso del tiempo: Así, no hay un concepto absoluto sino muchos y muchas adscripciones por distintos criterios tales como: la etnia, la lengua, el status socioeconómico, el género, la orientación sexual, y demás procesos de diferenciación social ${ }^{36}$.

Así, por ejemplo, en algunos casos, la migración indocumentada es de tránsito por lo que sería cuestionable hablar de minorías o algunas personas quizás podrían sostener que los índices de migración no son tan significativos como para hablar de minorías. La democracia es un sistema de vida en el cual prevalece el gobierno de las mayorías pero con pleno respeto a los derechos de las minorías; es decir, no se trata de una tiranía de las mayorías sino de la garantía efectiva de los derechos de todas las personas que se encuentran sujetas a la jurisdicción de los Estados por lo que no consiste en un asunto cuantitativo; así, aun cuando se trate de un migrante o de 10 millones de ellos, todos los Estados deben ofrecer garantías efectivas para el disfrute de sus derechos, independientemente de las minorías que puedan o no constituirse. Por ello se propone superar el debate en torno al término minoría para centrarse en el pleno respeto y garantía de los derechos de todas las personas que - regular o irregularmente - se encuentran en el territorio de un Estado.

Este debate aún abierto arroja indicios de que es factible utilizar el término de minorías para referirse a un grupo de personas migrantes indocumentadas. De esta conclusión parcial se desprende la procedencia de aplicar medidas afirmativas para la protección de este grupo en especial situación de vulnerabilidad y discriminación.

\footnotetext{
${ }^{36}$ Pérez Portilla, Karla, Aproximaciones al concepto de "minoría”, [en línea], disponible en: http://biblio.juridicas.unam.mx/libros/1/94/14.pdf, p. 262.
} 


\section{Dignidad e igualdad frente a las minorías}

Dignidad e igualdad son los presupuestos básicos para la protección de las minorías, incluidas las personas migrantes.

Como parte de esta obligación estatal debe tomarse en cuenta que no sólo se trata de enunciar derechos sino de decir cómo deben ser las políticas o acciones adecuadas para su defensa y vigencia.

Para Ferrajoli hay cuatro modelos de relación entre el derecho y las diferencias: a) indiferencia jurídica de las diferencias ${ }^{37}$; b) diferenciación jurídica de las diferencias38; c) homologación jurídica de las diferencias39; d) igual valoración jurídica de las diferencias ${ }^{40}$.

Existe un riesgo latente cuando en un territorio convergen minorías entre sí y éstas con la mayoría culturalmente predominante: el derecho del Estado puede buscar la uniformidad de las personas sujetas a su jurisdicción y de esta forma se puede afectar el ejercicio de los derechos, desconocer y limitar las distintas necesidades o formas de vida; es decir, una homogeneización que en el fondo parte de exclusiones y que desconoce las diferencias ${ }^{41}$.

En este marco, la alteridad permite pensar procesos y construir relaciones. Como tal constituye un referente central de la cultura y la vida diaria; mediante ella se puede analizar la tensión que involucra la relación con el otro. El otro es siempre el extranjero quien no es -necesariamente, ni casi nunca- un enemigo a combatir; aunque el otro - piensan algunos gobiernos - es el peligro que puede destruir la identidad ${ }^{42}$.

Es claro que sólo un nacionalismo moderado y democrático es justificable y se logra cuando se tiene como fundamento a los derechos humanos, los cuales proporcionan una base sólida posiblemente la única base sólida - para el pleno desarrollo social e individual.

El nacionalismo probablemente pueda visualizarse como contrapuesta a los derechos humanos ya que, en ocasiones, se desarrolla bajo una lógica incluyente que resulta excluyente al

37 Para este modelo las diferencias no se valorizan ni se desvalorizan, no se tutelan ni se reprimen, simplemente se les ignora. Cfr. Fer rajoli, Luigi, Igualdad y diferencia, [en línea], disponible en: $h t t p: / / c o n a p r e d . o r g . m x / d e p o s i-$ tobv/Mooo2-01.pdf [consultado el 10 de septiembre de 2016].

${ }^{38}$ De acuerdo con el cual se valorizan algunas identidades y se desvalorizan otras; aquellas que son valorizadas (como las identidades por razón de sexo, de nacimiento, de lengua, de fe religiosa, de renta, etcétera) resultan asumidas como estatus privilegiados y como fuentes de derechos y poderes. Las diferencias que no son valorizadas (por ejemplo la de mujer, judío, negro, hereje, apóstata, extranjero, apátrida, etcétera) se convierten en estatus discriminatorios, fuentes de exclusión y de sujeción, o a veces incluso de persecución. Ídem.

${ }^{39}$ Según el cual las diferencias son negadas e ignoradas en nombre de una abstracta afirmación de igualdad. Se trata del modelo de serialización llevado a cabo por los diversos socialismos reales y burocráticos. En este modelo se lleva a cabo una homologación, neutralización e integración de todos que elimina normativamente las diferencias y asume una identidad —en términos de sexo, clase, adhesión ideológica o religiosa - como normal y al mismo tiempo como normativa. Ídem.

${ }^{40}$ Se basa en el principio de igualdad en los derechos fundamentales y al mismo tiempo en un sistema de garantías capaz de asegurar su efectividad. De acuerdo con Ferrajoli, este modelo no ignora las diferencias, sino que al asegurar la igualdad de todos, en los derechos fundamentales, permite la afirmación y tutela de la propia identidad en virtud del reconocimiento del igual valor de todas las diferencias. Los derechos deberían permitir a cada persona y a cada grupo mantener y desarrollar su propia identidad, ya sea en forma individual o colectiva. Obviamente, Ferrajoli asocia el éxito de este modelo a la posibilidad de que existan garantías efectivas para hacer realidad los derechos.

${ }^{41}$ Gutiérrez Castañeda, Griselda (2008), "Identidad, Ciudadanía y Cultura Política”, en: Gómez Sollano, Marcela (coord.), Cultura política, integración de la diversidad e identidades sociales, UNAM, México, p. 83.

${ }^{42}$ Gómez Sollano y García Abigail (2008), “Alteridad, saber e integración de la diversidad”, en: Gómez Sollano, Marcela (Coord.), Cultura política [...], op. cit. nota 41 pp. 142 y 143. También cfr. Cohen, Esther y MARTíNezde la Escalera, Ana María (coords. 2002), Lecciones de extranjería, Una mirada a la diferencia, Instituto 
querer diluir las diferencias o restringirlas. Por tanto, hay que buscar una concepción del nacionalismo que sea compatible con los derechos humanos de todas las personas en el contexto de sociedades heterogéneas ${ }^{43}$.

En nuestras sociedades complejas resulta necesario replantearse la concepción jurídico-política de la ciudadanía, ya que tal concepción contempla exclusivamente el eje de la integración social, sin tener en cuenta mínimamente el otro gran eje de la diferenciación social, que se halla respaldado por los derechos humanos cuando son entendidos no sólo en el sentido individual, sino también en cuanto derechos de grupo (étnico, nacional, religioso, de género, etcétera). En este sentido, la ciudadanía sólo puede ser entendida, al finalizar la primera década del siglo XXI, como una ciudadanía compleja ${ }^{44}$. Porque hay que lograr que un conjunto de personas libres, autónomas y plurales, que conviven en un mismo contexto geográfico, estén integrados pero diferenciados a fin de que gocen y ejerzan plenamente sus derechos humanos.

Como se mencionó, los derechos humanos precisan del apoyo del régimen democrático, ya que sólo las democracias consolidadas - aun con riesgos de que los criterios para definir algo como consolidado puedan ser arbitrarios- pueden garantizar su cumplimiento. En este sentido puede decirse que la amplia difusión del modelo democrático en todo el mundo durante el último cuarto del siglo XX - aunque se trate con frecuencia de sistemas democráticos en transición, débiles o de fachada- abre una línea prometedora para la difusión del reconocimiento y de la observancia de los derechos humanos ${ }^{45}$.

En los últimos años se ha hablado de una ciudadanía diferenciad ${ }^{46}$; así, surge un concepto de ciudadanía diversificada que permite a los grupos sociales desfavorecidos o marginados y a las minorías, su integración en el Estado de que se trata sin perder por ello sus rasgos diferenciales propios. Se trata, entonces, de una ciudadanía heterogénea o, para manejarlo en otros términos, no homogénea.

La ciudadanía diferenciada propugnada por el multiculturalismo no se basa en el hecho de que el ciudadano ya no existe, que se está disolviendo de hecho, sino en el rechazo de un Estado considerado injusto que 'no ve' $y$, por tanto, oprime las diferencias étnico-culturales ${ }^{47}$.

Una de las propuestas calificadas como más radical ha sido la de Iris M. Young. A su juicio, el concepto hasta ahora hegemónico de ciudadanía integrada es un atentado contra el genuino concepto de igualdad, ya que viene a negar en la práctica los derechos de las minorías sociales y étnicas al forzarlas a una homogeneización con las pautas de la mayoría; y tal proceso homo-

de Investigaciones Filológicas UNAM, Siglo XXI, México, p. 8; y Wieviorka, Michel (20o6), "Cultura, sociedad y democracia”, en: Daniel Gutiérrez (coord.), Multiculturalismo: perspectivas y desafíos, El Colegio de México, UNAM, Siglo XXI, México, pp. 25-76.

${ }^{43}$ Ibídem, p. 11.

${ }^{44}$ Rubio Carracedo, José (200o), “Ciudadanía, Nacionalismo y Derechos Humanos”, en: Rubio Carracedo, José, Rosales, José María y Toscano Méndez, Manuel, Ciudadanía, Nacionalismo y Derechos Humanos, Trotta, Madrid, pp. 9 y 10.

45 Ibídem. p. 18.

${ }^{46}$ Cfr. Marshall (1950), Class, Citizenship and Social Development, Anchor, New York; y Kymlicka y Norman (1994), Return of the Citizen: A survey of Recent Work on Citizenship Theory, Ethics 104.

${ }^{47}$ Sartori, Giovanni (2001), La sociedad multiétnica. Pluralismo, multiculturalismo y extranjeros, trad. Miguel Ángel Ruiz de Azúa, Taurus, Madrid, p. 100. 
geneizador es también injusto puesto que contribuye a perpetuar su marginación sociocultural en beneficio de los grupos privilegiados de la mayoría ${ }^{48}$.

Ahora bien, ¿puede lograrse el respeto de las diferencias en los Estados multiculturales? y ¿cómo? He aquí, probablemente, uno de los mayores retos de las democracias occidentales.

Como una medida temporal para caminar hacia la igualdad sustancial, surgieron las acciones positivas, de discriminación positiva o inversa, igualación o acciones afirmativas, que son aquellas normas que diferencian entre colectivo socialmente beneficiado y desfavorecido y tienen como finalidad luchar contra la situación de desigualdad material de estos últimos.

Según Gimenez Glück las tres características principales de este tipo de medidas son:

la medida divide a la sociedad en colectivos cuya desigualdad material se manifiesta desde un punto de vista grupal, esto es, tiene como fundamento la igualdad material entre colectivos; y b) la medida tiene como finalidad compensar la desigualdad material que los beneficiados por la norma sufren desde un punto de vista colectivo; $y$ c) el rasgo que determina la diferenciación es la característica que los cohesiona como colectivo y por la que se identifica y discrimina socialmente a los miembros del mismo (ej.: el sexo, la raza, etc. $)^{49}$.

Una acción positiva ha sido definida como

el trato formalmente desigual que beneficia a un colectivo que comparte un rasgo estigmatizado (aunque) la racionalidad de las medidas que benefician a colectivo, en lugar de a individuos, son más difíciles de justificar. Las normas que benefician a un grupo tomando como fundamento su desigualdad material como colectivo, sin tener en cuenta caso a caso las circunstancias individuales, necesitan del refuerzo constitucional que supone la identificación de una serie de estos colectivos como especialmente protegibles.

Como se dijo las acciones positivas sean unas medidas estructuralmente temporales: en el momento en que el colectivo estigmatizado por uno de estos rasgos supere la desigualdad material, las acciones positivas devendrán inconstitucionales ${ }^{50}$.

Gimenez Glück, divide a las acciones positivas en dos categorías: las acciones positivas moderadas y las medidas de discriminación inversa.

Las medidas de discriminación inversa serían las acciones positivas consistentes en cuotas reservadas a los colectivos sensibles a la discriminación en los procesos selectivos para acceder a bienes escasos de la sociedad (puestos de trabajo, listas electorales, contratos con la Administración, plazas universitarias, etc.) Su carácter diferenciador estribaría en que provocan un daño mayor en los miembros de grupos no beneficiados por la diferencia de trato que el resto de acciones positivas, puesto que aqui ya no se trata de no obtener determinados ventajas reservadas a los colectivos objeto del plan, sino de perder derechos y bienes sociales que les hubieran correspondido si no se hubiera tenido en cuenta favorablemente el rasgo (sexo, raza, etc.) de sus competidores en el proceso selectivo sobre el que se proyectan.

Frente a las medidas de discriminación inversa, se contrapondrían las acciones positivas moderadas. Estas acciones positivas, en vez de influir directamente en el proceso selectivo para favorecer la elección de los miembros de los grupos desaventajados, como hacen las cuotas, tratan de remover los obstáculos que impiden a los miembros, de estos grupos llegar al proceso selectivo en igualdad de condiciones. Se adaptan mejor, pues, al concepto tradicional de

\footnotetext{
${ }^{48} \mathrm{Cfr}$. Young, Iris Marion (1990), Justice and the Politics of Difference, Princeton University Press, Princeton, N. J., passim.

${ }^{49}$ Gimenez Glück, David (2004), Juicio de igualdad y Tribunal Constitucional, Bosch, Barcelona, pp. 316- 320.

50 Ídem.
} 
igualdad de oportunidades: conseguir que todas las personas gocen de una posición similar en el punto de partida ${ }^{51}$.

Ahora bien, la justificación de las acciones positivas es clara: la fórmula que Aristóteles utilizó para definir la igualdad no sólo comprende la necesidad de tratar de forma igual a los iguales; además de eso, para alcanzar un sistema de justicia redistributiva lo suficientemente igualitario, se ha de tratar de manera desigual a los desigualmente situados ${ }^{52}$.

\section{Derecho a la igualdad y no discriminación}

La discriminación tiene que ver, en primer lugar, con relaciones políticas o de dominio - siempre de carácter inequitativo o asimétrico- que acontecen entre los grupos sociales pero en general a través de las relaciones entre personas; en segundo lugar, con un fenómeno de naturaleza fundamentalmente cultural, que halla sus fuentes en los prejuicios y en los procesos de estigmatización de los otros u otras. Un estereotipo es una visión generalizada o preconcepción de actitudes o características poseídas por personas integrantes de un grupo social particular (por ejemplo, las mujeres, las lesbianas o las indígenas) o los roles que realizan o deben realizar. Estas generalizaciones o preconcepciones con respecto a atributos, características o roles de miembros de un particular grupo social hacen innecesaria la consideración de las habilidades, necesidades, deseos y circunstancias de cualquier miembro particular del grupo ${ }^{53}$.

De acuerdo con el artículo 1 de la Convención Internacional sobre la Eliminación de todas la Formas de Discriminación Racial de Naciones Unidas, la discriminación es toda distinción, exclusión, restricción o preferencia basada en motivos de raza, color, linaje u origen nacional o étnico que tenga por objeto o por resultado anular o menoscabar el reconocimiento, goce o ejercicio, en condiciones de igualdad, de los derechos humanos y libertades fundamentales en las esferas política, económica, social, cultural o cualquier otra esfera de la vida pública.

El Convenio (número 111 de 1958) de la Organización Internacional del Trabajo (OIT) relativo a la discriminación en materia de empleo y ocupación ${ }^{54}$, define en su artículo $1^{\mathrm{o}}$ a la discriminación como a) Cualquier distinción, exclusión o preferencia basada en motivos de raza, color sexo, religión, opinión política, ascendencia nacional u origen social que tenga por efecto anular o alterar la igualdad de oportunidades o de trato en el empleo y la ocupación. b) Cualquier otra distinción, exclusión o preferencia que tenga por efecto anular o alterar la igualdad de oportunidades o de trato en el empleo u ocupación [...].

Existe una gran variedad de formas de discriminación, las cuales pueden ser ordenadas según algunos criterios de clasificación: el sujeto activo de la discriminación; el sujeto pasivo que sufre la discriminación; las causas o motivos con base en los cuales se realiza la discriminación; las consecuencias que se producen55. Otro criterio de clasificación se refiere a la diversidad de

\footnotetext{
${ }^{51}$ Ibídem, pp. 326- 328.

${ }^{52}$ Ibídem, p. 331.

${ }^{53}$ Consejo Nacional para Prevenir la Discriminación (2013), Fundamentos de la Armonización Legislativa con Enfoque Antidiscriminatorio, T. I., CONAPRED, México, p. 64.

54 Conocido como Convenio sobre la Discriminación (empleo y ocupación) de la Organización Internacional del Trabajo, adoptado en Ginebra, Suiza el 25 de junio de 1958, y entró en vigor el 15 de junio de 1960.

${ }^{55}$ Así se podría distinguir: la discriminación que priva de un bien o un derecho a una persona o grupo de personas con el que otros sí cuentan; la discriminación que excluye a una persona de participar de una situación u orden de cosas en las que otros toman parte; o la discriminación que impide u obstaculiza a una persona o grupo de personas realizar una actividad o derecho determinado del que otros sí pueden disfrutar.
} 
dimensiones en las que la discriminación se presenta: se puede identificar una dimensión personal, una dimensión institucional y una dimensión estructural.

La dimensión personal tiene su origen en los prejuicios de una persona concreta. La discriminación en su dimensión institucional se presenta en los contextos en que el acto discriminatorio se produce de manera regular debido a que su origen reside en criterios de conducta previamente establecidos en textos y documentos, así como en acuerdos no explícitos que rigen el funcionamiento de una determinada institución. La discriminación estructural se caracteriza en razón de que el acto discriminatorio se presenta de manera sistemática, lo cual se debe a que el orden social está dispuesto de manera tal que casi sin excepción ciertas personas o grupos de personas padecen la limitación o la negación de sus derechos. En esta dimensión la discriminación depende de las estructuras sociales ${ }^{56}$.

Es claro que en la realidad estas tres dimensiones de la discriminación no son excluyentes entre sí, más bien, a medida que se trasciende de la dimensión personal a la institucional y de ahí a la estructural, la anterior queda subsumida en la posterior, es decir, la discriminación estructural se conforma y se manifiesta a través de un gran número de discriminaciones personales e institucionales, esta última mediante una serie de discriminaciones personales ${ }^{57}$.

A pesar de lo anterior, hay que aclarar que no toda distinción o diferenciación constituye discriminación.

La Corte IDH ha establecido que es discriminatoria una distinción que carezca de justificación objetiva y razonable. Por consiguiente, los Estados tienen la obligación de no introducir en su ordenamiento jurídico regulaciones discriminatorias, eliminar las regulaciones de carácter discriminatorio, combatir las prácticas de este carácter y establecer normas y otras medidas que reconozcan y aseguren la efectiva igualdad ante la ley de todas las personas ${ }^{58}$. Éstos y otros aspectos de la jurisprudencia de la Corte IDH serán abordados en posteriores capítulos ${ }^{59}$.

Ahora bien, el principio de igualdad obliga no sólo a suprimir las discriminaciones existentes, sino también a establecer medidas positivas a favor de colectivos que están en situaciones de desventaja real. En la jurisprudencia del Tribunal Europeo, en el caso Stec y otros contra Reino

${ }^{56}$ De la Torre Martínez, Carlos (2006), El Derecho a la no discriminación en México, Porrúa, Comisión Nacional de los Derechos Humanos, México, pp. 7-9.

57 Ídem.

${ }^{58}$ Véase Corte Interamericana de Derechos Humanos, Caso Yatama, sentencia de 23 de junio de 2005; Opinión Consultiva OC-18/o3, Condición Jurídica y Derechos de los Migrantes Indocumentados, 17 de septiembre de 2003; Opinión Consultiva OC-17/o2, Condición Jurídica y Derechos Humanos del Niño, 28 de agosto de 2002 y Opinión Consultiva OC-4/84, Propuesta de Modificación a la Constitución Política de Costa Rica relacionada con la Naturalización, 19 de enero de 1984. El Tribunal Europeo de Derechos Humanos también ha sostenido este razonamiento, véase caso relativo a determinados aspectos del régimen lingüístico de la enseñanza en Bélgica, sentencia de 23 de julio de 1968; Caso Kjeldsen, BuskMadsen y Pedersen, sentencia de 7 de diciembre de 1976; Caso Marckx, sentencia de 13 de junio de 1979; Caso Artico, sentencia de 13 de mayo de 1980; Caso RefahPartisi, Erbakan, Kazan $y$ Tekdal, sentencia 31 de julio de 2001. En un sentido similar - y a manera de ejemplo-se encuentra la jurisprudencia del Pleno de la Suprema Corte de Justicia Mexicana al afirmar que:

La garantía de no discriminación que consagra el tercer párrafo del artículo 1o. constitucional, proscribe cualquier
distinción motivada por razones de género, edad, condición social, religión o cualquier otra análoga que atente contra
la dignidad humana y tenga por objeto anular o menoscabar los derechos y libertades de las personas; sin embargo, no
es cualquier distinción de trato entre las personas, sino sólo aquellas que atenten contra la dignidad humana, así como
las que tengan por efecto anular o menoscabar sus derechos y libertades, o bien, la igualdad real de oportunidades.

Novena Época, Semanario Judicial de la Federación y su Gaceta XXVIII, Octubre de 2008, p. 25, tesis: P./J. $114 / 2008$.

${ }^{59}$ Corte Interamericana de Derechos Humanos, Sumarios de Jurisprudencia. Igualdad y no discriminación, Center forJustice and International Law, Washington, 2009. 
Unido de 12 de abril de 2006, se utiliza en la argumentación el concepto de medidas de acción positiva, aunque sin emplear tal denominación. Si bien señala también que en esa materia, los Estados gozan de un amplio margen de apreciación nacional ${ }^{60}$.

La Corte IDH ha señalado que:

la noción de igualdad se desprende directamente de la unidad de naturaleza del género humano y es inseparable de la dignidad esencial de la persona, frente a la cual es incompatible toda situación que, por considerar superior a un determinado grupo, conduzca a tratarlo con privilegio; o que, a la inversa, por considerarlo inferior, lo trate con hostilidad o de cualquier forma lo discrimine del goce de derechos que sí se reconocen a quienes no se consideran incursos en tal situación de inferioridad. No es admisible crear diferencias de tratamiento entre seres humanos que no se correspondan con su única e idéntica naturaleza ${ }^{61}$.

La igualdad de hecho atiende a las condiciones de los sectores o grupos de personas social, económica o culturalmente menos favorecidos, e impone al Estado, mediante la realización de acciones positivas, el deber de remover los obstáculos que impidan a tales personas un ejercicio real y efectivo de sus derechos fundamentales, como así también gozar de una igualdad de oportunidades o de resultados, según los bienes y aspectos con relación a los cuales se pretenda alcanzar dicha igualdad ${ }^{62}$.

Así, para la Corte Suprema de Argentina, el principio de igualdad resultaría vulnerado si se contemplare en forma idéntica casos que entre sí son diferentes ${ }^{63}$.Según la Corte Suprema de Estados Unidos de América, a veces la mayor discriminación puede consistir en tratar cosas que son diferentes como si fueran exactamente iguales ${ }^{64}$. Como acertadamente lo ha puesto de manifiesto la Corte Interamericana, existen ciertas desigualdades de hecho que pueden traducirse, legítimamente, en desigualdades de tratamiento jurídico, sin que esto contraríe la justicia. Más aún, tales distinciones pueden ser un instrumento para la protección de quienes deban ser protegidos, considerando la situación de mayor o menor debilidad o desvalimiento en que se encuentran ${ }^{65}$.

La Corte IDH ha destacado que el deber de respetar y garantizar los derechos humanos emana del principio de igualdad, señalando que

existe un vínculo indisoluble entre la obligación de respetar y garantizar los derechos humanos y el principio de igualdad y no discriminación. Los Estados están obligados a respetar y garantizar el pleno y libre ejercicio de los derechos y libertades sin discriminación alguna. El incumplimiento por el Estado, mediante cualquier tratamiento discriminatorio, de la obligación general de respetar y garantizar los derechos humanos, le genera responsabilidad internacional.

\footnotetext{
${ }^{60}$ Santolaya Machetti, Pablo y Díaz Ricci, Sergio (2012), "Los derechos económicos, sociales y culturales y la protección de grupos vulnerables”, en: GArcía RocA, Javier et. al. (eds.), El Diálogo entre los sistemas Europeo y Americano de Derechos Humanos, Civitas, Thomson Reuters, Pamplona, pp. 294 y 295.

${ }^{61}$ Propuesta de modificación a la Constitución Política de Costa Rica relacionada con la naturalización. Opinión Consultiva OC-4/84, de 19 de enero de 1984, Serie A. núm. 4, párr. 55. Cfr. Didier, María Marta (2012), El principio de igualdad en las normas jurídicas. Estudio de la doctrina de la Corte Suprema de Argentina y su vinculación con los estándares de constitucionalidad de la jurisprudencia de la Corte Suprema de Estados Unidos, Marcial Pons, Buenos Aires, p. 25.

${ }^{62}$ Ibidem, pp. 35 y 36.

${ }^{63}$ Fallos, 327:4495 (2004).

${ }^{64}$ Jennes vs. Fortson, 403 U:S: 431 (1971).

${ }^{65}$ Corte IDH. Condición jurídica y derechos humanos del niño, Opinión consultiva OC-17/2002, del 28 de agosto de 2002, Serie A núm. 17, párr. 46. Didier, María Marta (2012), El principio de igualdad..., op. cit., nota 61, pp. 39 y 40 .
} 
Los derechos humanos no deben su origen a la condición o rol de la persona, sino que son inherentes al hecho de ser hombre: por eso [...], las declaraciones y pactos internacionales sobre esos derechos insisten reiteradamente que los posee todo hombre con independencia de cualquier condición ${ }^{66}$.

En este marco, Alfonso Ruiz Miguel observa que la igualdad es un concepto relacional que muestra la identidad que existe entre dos o más personas, cosas o hechos en relación tan sólo con algunos aspectos, reconociendo las diferencias sustanciales que prevalecen en el resto de los elementos ${ }^{67}$. También se ha hablado de la igualdad como regla y como principio ${ }^{68}$.

Al pensar en igualdad, según Dworkin, es necesario vislumbrar la existencia de dos principios relevantes en su configuración. El primero es el principio de igual importancia y el segundo es el principio de responsabilidad especial.

El principio de igual importancia no exige que los seres humanos sean iguales en todo, más bien exige que el gobierno adopte leyes y políticas que aseguren que el destino de los ciudadanos, en la medida de lo posible para un gobierno, no se vea afectado por ser quienes son (conforme a su situación económica, su género, su raza, o sus habilidades o minusvalías concretas). El principio de responsabilidad especial demanda que el gobierno trabaje, de nuevo en la medida de lo posible, para conseguir que el destino de las personas dependa de lo que cada una elige.

Así, se ha dicho que

los antiguos igualitaristas insistían en que una comunidad politica tiene la responsabilidad colectiva de tratar con igual consideración a todos sus ciudadanos, pero definieron esa igualdad de consideración de forma que no se tenían en cuenta las responsabilidades personales de los ciudadanos. Los conservadores -nuevos y viejos- insistieron en esa responsabilidad personal, pero la definieron de manera que no se tenía en cuenta la responsabilidad colectiva.

Frente a estas dos opciones es necesario buscar una explicación unificada de la igualdad y la responsabilidad que las respete a las $\operatorname{dos}^{69}$. Si se entiende lo anterior como una tercera vía, en la cual la obligación del Estado queda claramente definida y es asumida por todos los actores públicos en beneficio de los derechos humanos, entonces esa es la vía que se plantea en este trabajo.

En dicho marco, igualdad y diferencia no son conceptos antónimos, por el contrario, se exigen mutuamente. La igualdad no implica la homogeneidad en relación con las formas de ser, actuar y pensar de las personas.

Ya se ha dicho que, para determinar el significado específico de una relación de igualdad, es necesario responder al menos a dos preguntas:

¿Igualdad entre quiénes? ¿ ¿Igualdad en qué? Limitando el criterio de especificación a la pareja todo-parte, las respuestas posibles son cuatro: a) igualdad entre todos en todo; b) igualdad entre todos en alguna cosa; c) igualdad entre algunos en todo; d) igualdad entre algunos en alguna cosa. El ideal-límite del igualitarismo se reconoce en la primera respuesta: igualdad

\footnotetext{
${ }^{66}$ Cfr. Condición jurídica y derechos de los migrantes indocumentados. Opinión Consultiva OC 18/03, de 17 de septiembre de 2003, Serie A, núm. 18, párr. 86.

${ }^{67}$ Cfr. Ruiz Miguel, Alfonso (2003), "Sobre el concepto de igualdad”, en: Carbonell, Miguel (comp.), El principio constitucional de igualdad. Lecturas de introducción, Comisión Nacional de los Derechos Humanos, México, pp. 31-67.

${ }^{68}$ Soberanes Díez, José María (2011), La igualdad y la desigualdad jurídicas, Porrúa, México, p. 31. Cfr. también Alexy, Robert (1993), Derecho y razón práctica, Fontamara, México, pp. 16 y 86.

${ }^{69}$ DwOrkin, Ronald (2003), Virtud soberana. La teoría y la práctica de la igualdad, Paidós, Barcelona, pp.15-17.
} 
de todos los hombres en todos los aspectos. Pero, precisamente, se trata de un ideal-límite prácticamente inalcanzable ${ }^{70}$.

Valdría la pena repreguntar si realmente la igualdad de todas las personas en todos los aspectos es inalcanzable y mientras respondemos esa pregunta - seguramente de manera negativa - quizás debamos tender a consolidar —o en su caso, alcanzar-la igualdad para el mayor número de seres humanos en el mayor número de aspectos.

En otro sentido, y como es conocido, la igualdad tiene dos dimensiones: la igualdad material y la igualdad formal. La material implica la igualdad de las personas dentro de la realidad social. La igualdad formal, en cambio, implica la idéntica consideración jurídica de las personas ${ }^{71}$. Los Estados han centrado la lucha en la igualdad formal y han logrado grandes avances en este ámbito. Sin embargo, el verdadero reto actualmente radica en la igualdad material y en cómo superar los obstáculos que han impedido que la igualdad jurídica se convierta en una realidad vivencial.

La desigualdad material se configura como fundamento de muchas leyes, que clasifican precisamente en función de la posición económica y social de sus destinatarios. Estas leyes son perfectamente constitucionales por tratar de forma diferente a supuestos de hecho distintos, teniendo en cuenta que esa disimilitud se manifiesta respecto a la posesión de bienes y oportunidades, esto es, respecto a la igualdad material. Las normas que respondan a una situación individual se conocerán como medidas de igualación positiva. Las que compensen una desigualdad material de grupo se denominan acciones positivas.

Se ha dicho que:

el término "acción positiva" parece más correcto que el comúnmente utilizado de discriminación positiva, puesto que no estamos aquí ante desigualdades en la norma constitucionalmente inaceptables - discriminación - sino ante una especial clase de diferenciación constitucionalmente aceptable que necesita una justificación reforzada al referirse a colectivos, y no a individuos. Sólo a una determinada especie de acciones positivas -las cuotas en procesos

\footnotetext{
$7^{70}$ Bobbio, Norberto (1993), Igualdad y Libertad, Paidós, Barcelona, p. 78.

${ }^{71}$ Soberanes Díez, José María (2011), La igualdad... op. cit. nota 68, p. 171.
} 
de selección para miembros de los colectivos beneficiados-se le denominará "medidas de discriminación inversa", por su especial controversia constitucional ${ }^{72}$.

La diferencia entre las medidas de igualación positiva y las acciones positivas estriba, por tanto, en el sujeto de la medida: los individuos en el primer caso; los colectivos en el segundo ${ }^{73}$.

Según María Didier, la doctrina favorable a la discriminación inversa ha señalado que esta medida sólo podrá considerarse constitucionalmente legítima y no violatoria del principio de igualdad, en caso de que se superen los siguientes juicios:

a) Teniendo en cuenta su finalidad: sólo se justificarían si tienen por objetivo«...remediar los perdurables efectos desfavorables de discriminaciones de hondo arraigo social, como la sexual y la racial. Esto determina que fuera del cumplimiento de dicha finalidad, las discriminaciones inversas se transforman en inaceptables discriminaciones directas». Por tanto, no cualquier objetivo podrá ser considerado como constitucionalmente legítimo ni proporcionando a los medios utilizados, sino tan sólo aquel que se dirija a superar una profunda discriminación racial, sexual, o, cabe agregar, por razón de la minusvalía, mediante la redistribución de bienes sociales escasos entre tales colectivos tradicionalmente excluidos.

b) Deben superar el juicio de necesidad, pues «sólo podrá acudirse a la regulación por cuotas cuando no sea posible lograr el mismo objetivo de igualdad en un sector social determinado y en un tiempo razonable a través de otras medidas menos extremas de acción positiva». Si resulta factible alcanzar igual objetivo mediante la implementación de acciones positivas moderadas, la aplicación de la discriminación inversa resultará contraria al principio de igualdad. A su vez, y también como exigencia del juicio de necesidad, deben limitarse al período de tiempo y estrictamente indispensable para alcanzar el objetivo propuesto. Por ello, no pueden prolongarse en el tiempo indefinidamente.

c) Para superar el juicio de proporcionalidad en sentido estricto, la medida no debe suponer un daño excesivo a individuos no pertenecientes a la minoría favorecida, y por supuesto, no

Algunas de estas medidas no serán constitucionales, por tratarse de cuotas rígidas que producen un daño desproporcionado a tercero: se les conocerá como medidas de discriminación inversa en estado puro. Otras, pese a su especial dificultad, superarán el test de constitucionalidad. Son las medidas de discriminación inversa nacionalizadas. En este caso, el término discriminación no se corresponde con diferenciación inconstitucional sino con diferenciación especialmente lesiva, pese a su constitucionalidad. Al resto de acciones positivas - las que no constituyen cuotas - se las conocerá como acciones positivas moderadas. En cuanto al término medidas de igualación positiva es un término propio que trata de definir el conjunto de medidas que, basándose en la igualdad material afectan a situaciones individuales [...] Una medida de igualación positiva es la norma que, partiendo de una situación de desigualdad entre ciudadanos individualmente considerados, tiene como objetivo promover, desde un punto de vista individual, la igualdad material de los más desfavorecidos. Las tres características principales de este tipo de medidas son: a) la medida divide a la sociedad en ciudadanos cuya igualdad material se manifiesta individualmente, esto es, tiene como fundamento la igualdad material entre individuos; b) la finalidad de la misma es compensar la desigualdad material que los beneficiados sufren desde un punto de vista individual; y c) el rasgo que determina la diferenciación es un signo objetivo, indubitado o intemporal de inferioridad social de los individuos beneficiados. La diferencia con la acción positiva se manifiesta en el carácter individual del rasgo diferenciados y en la finalidad; mientras la medida de igualación positiva, basándose en un rasgo objetivo e indubitado de inferioridad social, como la falta de ingresos o una minusvalía, diferencia entre individuos socialmente perjudicados y favorecidos y tiene como objetivo invertir la desigualdad material de los primeros, la acción positiva diferencia entre colectivos socialmente beneficiados y desfavorecidos y tiene como finalidad luchar contra la situación de desigualdad material de estos últimos. El ejemplo más nítido de medida de igualación positiva es, quizás, la clasificación legislativa que beneficia a los más desfavorecidos desde un punto de vista estrictamente económico, esto es, que toma como rasgo diferenciador un elemento económico objetivo. GIMENEZ GLÜck, David (2004), Juicio de igualdad [...], op. cit. nota 49, pp. 310-316.

${ }^{73}$ Ídem. 
podrá privar a persona alguna de un derecho humano. Esto último supone sortear el juicio de alteración del contenido esencial del derecho humano en juego.

d) Con relación a la carga de la prueba, quienes propongan la medida deberán acreditar objetiva y fehacientemente la desigualdad de hecho en el ámbito concreto de la realidad social de que se trate. Aquí tienen especial relevancia los estudios estadísticos.

e) Sólo podrán establecerse mediante le $y^{74}$.

Todo lo anterior conduce a pensar si el principio de igualdad y no discriminación sirve para ampliar el goce de derechos a migrantes irregulares frente a lo cual la respuesta se vislumbra afirmativa, particularmente en contextos marcados por discursos de odio.

Ante esto se podría considerar que si se amplían los derechos del conjunto de personas que se encuentran en un país dicho beneficio debería considerarse extensivo para los migrantes, aún en situación irregular. Sin embargo, ¿qué pasa si amplio el catálogo de derechos para todas las personas sujetas a la jurisdicción de un Estado y excluyo a los migrantes irregulares? La respuesta es clara, dicha medida -si es injustificada, desproporcionada y no persigue un fin legítimo- es discriminatoria para los migrantes y, en consecuencia, el Estado violenta el principio de igualdad y no discriminación que se configura como una norma de jus cogens.

Los discursos de odio se erigen como una forma de discriminación violatoria del Derecho Internacional de los Derechos Humanos y de las normas de juscogens. Por lo anterior, los Estados tienen la obligación de prevenir acciones y omisiones que puedan detonar procesos de violencia y discriminación basados en discurso de odio o estereotipos culturales. Además deben diseñar acciones afirmativas que permitan el pleno goce y ejercicio de los derechos humanos en su territorio, incluyendo los derechos humanos de las personas migrantes irregulares que se encuentren sujetas a procesos administrativos de expulsión o deportación.

\section{A manera de conclusión}

Enunciar un apartado de conclusiones es sumamente complejo, particularmente en un tema como el que ocupa a este trabajo. Por ello se enunciarán algunas ideas de manera provisional.

A inicios de 2017 - pero también en otros periodos y puntos geográficos- hemos observado la exacerbación de ideas que podrían creerse ya superadas pero que siempre han estado presentes. Ideas vinculadas a la protección frente a amenazas del exterior, el derroche de recursos que implica la protección de derechos de ciertos sectores de población o la percepción de la migración como un problema de seguridad y no de desarrollo humano.

Frente al dilema económico que plantean los derechos $-\mathrm{y}$ particularmente en referencia a México y Estados Unidos de América-, Sunstein y Holmes parten de una premisa que parecería evidente: los derechos cuestan dinero. Sin embargo, dicha premisa no ha sido asumida ni entendida por los Estados. Es fundamental entender cómo se vinculan los derechos civiles y

\footnotetext{
${ }^{74}$ Didier, María Marta (2012), El principio de igualdad en las normas jurídicas. Estudio de la doctrina de la Corte Suprema de Argentina y su vinculación con los estándares de constitucionalidad de la jurisprudencia de la Corte Suprema de Estados Unidos, Buenos Aires, Marcial Pons, pp. 162 y 163.
} 
políticos con aquellos que parecen edificarse como "normas programáticas": unos y otros imponen compromisos económicos.

El argumento de que los derechos de las personas migrantes no pueden ser garantizados por falta de recursos es débil ya que todos los derechos humanos implican costos y la decisión política de cumplir con ellos es justamente eso, una decisión política.

No hay derechos gratuitos y, por tanto, con una adecuada redistribución y austeridad gubernamental en rubros operativos, los derechos de las personas migrantes podrían ser garantizados.

La justicia constitucional no lo puede todo, se requieren medios económicos (máximo uso de los recursos disponibles) pero si los Estados son omisos en esta responsabilidad incurrirían en inconvencionalidades o inconstitucionalidades.

Los derechos cuestan dinero. Todos ellos, ya se trate de las libertades tradicionales a la no interferencia estatal (libertades negativas), ya de los derechos sociales, usualmente identificados como aquellos que exigen el despliegue de una actividad más directa por parte del Estado (libertades positivas) [...] todos los derechos son positivos ${ }^{75}$.

Sunstein y Holmes definen a los derechos humanos como bienes públicos: servicios sociales financiados por los contribuyentes y administrados por el Estado para mejorar el bienestar colectivo e individual ${ }^{76}$.

Ahora bien hay que tener presente que la protección contra el gobierno es impensable sin la protección "del" gobierno [...]. Ningún sistema jurídico puede proteger a la gente contra los funcionarios públicos sin antes defenderla por medio de los funcionarios públicos ${ }^{77}$.

Por tanto, un argumento no puede ser la falta de recursos para garantizar derechos humanos de migrantes indocumentados; tampoco es argumento el que dichos derechos son normas programáticas de realización futura e incierta. Si todos los derechos cuestan, se deben comenzar a priorizar los derechos de los migrantes indocumentados. Claramente éstos no inciden en los resultados electorales -ya que los derechos político-electorales de los extranjeros indocumentados son inexistentes-; a pesar de ello sus derechos deben ser respetados y garantizados en igualdad de circunstancias que las personas nacionales del país de que se trate. La obligación del Estado en este sentido es indeclinable.

Por lo anterior, es urgente activar los mecanismos posibles en sede internacional que permitan supervisar a los Estados en el cumplimiento de sus obligaciones en materia de derechos humanos. Con ello se puede fortalecer la exigibilidad de los derechos humanos de las personas migrantes, particularmente al seno de la Organización de las Naciones Unidas y de la Comisión Interamericana de Derechos Humanos (o de la Corte Interamericana de Derechos Humanos, en el caso de aquellos Estados que ya han aceptado la competencia contenciosa de la misma).

Finalmente, y en torno a la conversión o transformación de la igualdad jurídica en desigualdad de facto, Atienza explica que estas paradojas pueden originarse en virtud de que:

El Derecho - también el de los Estados democráticos - presta forma y contenido a la injusticia del mundo contemporáneo", cuyo rasgo central es el abismo cada vez mayor entre los ricos y los pobres, entre los poderosos y los sometidos, un abismo que separa no sólo a unas sociedades de otras, sino a unos individuos de otros que forman parte de la misma sociedad. Lo que genera ese estado de cosas no es simplemente la existencia de acciones jurídicamente ilícitas, de comportamientos delictivos. "La injusticia de nuestro mundo es, en muy buena medida, una injusticia jurídica, legal; un resultado de respetar el derecho, no de infringirlo [...]".

\footnotetext{
${ }^{75}$ Holmes, Stephen y Sunstein, Cass (2012), El costo de los derechos. Por qué la libertad depende de los impuestos, Siglo XXI Editores, Buenos Aires, p. 16.

${ }^{76}$ Ibídem, p. 69.

${ }^{77}$ Ibídem, p. 77.
} 
Esta ambigüedad del "Derecho" contemporáneo, el que sea "al mismo tiempo un factor de liberación y de opresión", no tiene, en realidad, nada de paradójico [...] y dado que vivimos en sociedades signadas por la desigualdad o la injusticia, sería extraño que el Derecho [...] no reflejara de alguna forma esa circunstancia [...] Lo que da sentido al Derecho no puede ser otra cosa que la aspiración a la justicia o, para decirlo en términos más modestos o más realistas: "la lucha contra la injusticia ${ }^{78}$.

\section{Fuentes}

\section{Bibliográficas}

Alexy, Robert (1993), Derecho y razón práctica, Fontamara, México.

Atienza, Manuel (2001), El sentido del Derecho, Ariel, Barcelona.

Воввіо, Norberto (1993), Igualdad y Libertad, Paidós, Barcelona.

Bodino, Jean (19073), Los seis libros de la república, trad. Pedro Bravo, Aguilar, Madrid.

Bovero, Michelangelo (2002), "Ciudadanía y derechos fundamentales”, en: Boletín Mexicano de Derecho Comparado, núm. 103, enero-abril de 2002.

Bustamante, Jorge (2003), "La paradoja de la autolimitación de la soberanía: derechos humanos y migraciones internacionales" en: Prevención de la violencia, atención a grupos vulnerables y los derechos humanos. Los derechos de los migrantes, fascículo 5, Comisión Nacional de los Derechos Humanos, México.

(2002), Migración internacional y derechos humanos, UNAM, Instituto de Investigaciones Jurídicas, México.

La paradoja de la autolimitación de la soberanía: derechos humanos y migraciones internacionales, [en línea], disponible en: https://archivos.juridicas.unam.mx/ www/bjv/libros/1/342/8.pdf.

Caballero, Ángel (2005), Constitución y realidad constitucional, Porrúa, Tecnológico de Monterrey, México.

Carbonell, Miguel (2009), Dilemas de la democracia constitucional, Porrúa, Cámara de Diputados, Comisión Estatal de Derechos Humanos de Aguascalientes, México.

(2006), “¿Se justifican las fronteras en el siglo XXI?”, en: Este país. Tendencias y opiniones, número 189 , diciembre.

(comp. 2003), El principio constitucional de igualdad. Lecturas de introducción, Comisión Nacional de los Derechos Humanos, México.

Carrillo Salcedo, Juan Antonio (1969), Soberanía del Estado y derecho internacional, Tecnos, Madrid.

\footnotetext{
${ }^{78}$ Atienza, Manuel (2001), El sentido del Derecho, Ariel, Barcelona, pp. 311 y 312. Énfasis propio. 
(2001), Soberanía de los Estados y Derechos Humanos en Derecho Internacional Contemporáneo, $2^{\text {a }}$ ed., Tecnos, Madrid.

Cohen, Esther, et al., (coords. 2002), Lecciones de extranjería, mirada a la diferencia, Instituto de Investigaciones Filológicas UNAM, Siglo XXI, México.

De LuCAs, Javier (1994), El desafío de las fronteras. Derechos humanos y xenofobia frente a una sociedad plural, Temas de Hoy, Madrid.

De la Torre Martínez, Carlos (2006), El Derecho a la no discriminación en México, Porrúa, Comisión Nacional de los Derechos Humanos, México.

Didier, María Marta (2012), El principio de igualdad en las normas jurídicas. Estudio de la doctrina de la Corte Suprema de Argentina y su vinculación con los estándares de constitucionalidad de la jurisprudencia de la Corte Suprema de Estados Unidos, Marcial Pons, Buenos Aires.

Donnelly, Jack (1998), Derechos humanos universales en teoría y en la práctica, Gernika, México.

DwORKIn, Ronald (2003), Virtud soberana. La teoría y la práctica de la igualdad, Paidós, Barcelona.

Ferrajoli, Luigi, Igualdad y diferencia, [en línea], disponible en: http://conapred.org.mx/depositobv/Mooo2-o1.pdf [consultado el 10 de septiembre de 2016].

García QuiÑones, Rolando, et al. (2002), "La migración internacional en el nuevo escenario. El dilema de las fronteras", en: Revista de la Universidad de la Habana, 254/255, segundo semestre 2001-primer semestre, La Habana.

García RocA, Javier et. al. (eds., 2012), El Diálogo entre los sistemas Europeo y Americano de Derechos Humanos, Civitas, Thomson Reuters, Pamplona.

Gimenez Glück, David (2004), Juicio de igualdad y Tribunal Constitucional, Bosch, Barcelona.

Gómez Sollano, Marcela (coord. 2008), Cultura política, integración de la diversidad e identidades sociales, UNAM, México.

Gutiérrez, Daniel (coord. 2006), Multiculturalismo: perspectivas y desafíos, El Colegio de México, UNAM, Siglo XXI, México.

HäBerle, Peter, et al. (2003), De la soberanía al derecho constitucional común: palabras clave para un diálogo europeo-latinoamericano, trad. Héctor Fix-Fierro, UNAM, México.

Holmes, Stephen y Sunstein, Cass (2012), El costo de los derechos. Por qué la libertad depende de los impuestos, Siglo XXI Editores, Buenos Aires.

Ibarra Palafox, Francisco (2005), Minorías etnoculturales y Estado nacional, UNAM, México. 
KyMlickA, Will, et al. (2003), Cosmopolismo, Estado-nación y nacionalismo de las minorías. Un análisis crítico de la literature reciente, UNAM, México.

(1994), Return of the Citizen: A survey of Recent Work on Citizenship Theory, Ethics 104.

Marshall (1950), Class, Citizenship and Social Development, Anchor, New York, 1950.

Merton, Robert (1964), Teoría y estructura sociales, Fondo de Cultura Económica, México.

Nino, Carlos Santiago (1992), Un país al margen de la ley. Estudio de la anomia como componente del subdesarrollo argentino, Buenos Aires, Emecé, 1992.

Pérez Portilla, Karla, Aproximaciones al concepto de "minoría", [en linea], disponible en: http://biblio.juridicas.unam.mx/libros/1/94/14.pdf.

RABAT, Plan of Action on the prohibition of advocacy of national, racial or religious hatred that constitutes incitement to discrimination, hostility or violence. Conclusions and recommendations emanating from the four regional expert workshops organized by OHCHR in 2011, and adopted by experts at the meeting in Rabat, Marruecos, 5 de octubre de 2012, [en línea], disponible en: http://www.ohchr.org/Documents/HRBodies/ HRCouncil/RegularSession/Session22/A-HRC-22-17-Add4_sp.pdf.

Rubio Carracedo, José, Rosales, José María y Toscano Méndez, Manuel (2000), Ciudadanía, Nacionalismo y Derechos Humanos, Trotta, Madrid.

SARtori, Giovanni (2001), La sociedad multiétnica. Pluralismo, multiculturalismo y extranjeros, trad. Miguel Ángel Ruiz de Azúa, Taurus, Madrid.

Soberanes Díez, José María (2011), La igualdad y la desigualdad jurídicas, Porrúa, México.

Young, Iris Marion (1990), Justice and the Politics of Difference, Princeton University Press, Princeton, N. J.

Zagrebelsky, Gustavo (2007), El derecho dúctil. Ley, derechos y justicia, $7^{\mathrm{a}}$. ed., trad. de Marina Gascón, Trotta, Madrid.

Zolo, Danilo (1999), “La strategiadellacittadinanza”, en: Zolo, Danilo (ed.), La Cittadinanza. Appartenenza, identitádiritti, 2ª ${ }^{\text {a }}$ Ed. Roma-Bari, Laterza.

Zovatto, Daniel, et. al. (2005), Argentina: Una sociedad anómica. Encuesta de cultura constitucional, UNAM, Asociación Argentina de Derecho constitucional, Idea Internacional, México.

\section{Legislativas e institucionales}

Amparo directo en revisión 2806/2012. Enrique Núñez Quiroz. 6 de marzo de 2013.

Asamblea General de la ONU en su resolución 47/135 del 18 de diciembre de 1992. 
Asunto Féret c. Bélgica ( ${ }^{\circ}$ 15615/07), de 16 de julio de 2009.

Asunto MüslümGündüzc. Turquía (nº35071/97).

Caso relativo a determinados aspectos del régimen lingüístico de la enseñanza en Bélgica, sentencia de 23 de julio de 1968.

Caso Kjeldsen, BuskMadsen y Pedersen, sentencia de 7 de diciembre de 1976; Caso Marckx, sentencia de 13 de junio de 1979.

Caso Artico, sentencia de 13 de mayo de 1980; Caso RefahPartisi, Erbakan, Kazan y Tekdal, sentencia 31 de julio de 2001.

Comisión Interamericana de Derechos Humanos. Informe Anual 2009. Informe Anual de la Relatoría Especial para la Libertad de Expresión. Capítulo II (Marco Jurídico Interamericano sobre el Derecho a la Libertad de Expresión). OEA/Ser.L/V/II. Doc. 51. 30 de diciembre de 2009.

Comité para la Eliminación de la Discriminación Racial, Observación general No. 35 (CERD/C/GC/35), párr. 6, [en línea], disponible en: http://tbinternet.ohchr.org/_layouts/treatybodyexternal/Download.asp x?symbolno=CERD\%2fC\%2fGC\%2f35\&Lang= en.

Consejo Nacional para Prevenir la Discriminación (2013), Fundamentos de la Armonización Legislativa con Enfoque Antidiscriminatorio, T. I., CONAPRED, México.

Corte Interamericana de Derechos Humanos, Sumarios de Jurisprudencia. Igualdady no discriminación, Center for Justice and International Law, Washington, 2009. (2005), Caso de las niñas Yean y Bosico, sentencia de 8 de septiembre.

Decisión marco 2008/913/JAI del Consejo de Europa, emitida el 28 de noviembre de 2008, [en línea], disponible en: http://eur-lex.europa.eu/legal-content/ES/ TXT/?uri=URISERV\%3Al33178.

Opinión Consultiva OC-18/o3, Condición Jurídica y Derechos de los Migrantes Indocumentados, 17 de septiembre de 2003.

Opinión Consultiva OC-17/o2, Condición Jurídica y Derechos Humanos del Niño, 28 de agosto de 2002.

Opinión Consultiva OC-4/84, Propuesta de Modificación a la Constitución Política de Costa Rica relacionada con la Naturalización, 19 de enero de 1984.

Recomendación 1805 (2007) de la Asamblea Parlamentaria del Consejo de Europa sobre Blasfemia, insultos religiosos y discursos de odio contra personas por causa de su religión, [en línea], disponible en: http://www.assembly.coe.int/nw/xml/XRef/Xref$X M L_{2} H T M L$-en.asp?fileid=17569\&lang=en. 
Recomendación No. R (97) 20 emitida por el Comité de Ministros del Consejo de Europa, [en línea], disponible en: https://rm.coe.int/CoERMPublicCommonSearchServices/Di splayDCTMContent?documentId=0900001680505d5b.

Tesis: P./J. 114/2008, Semanario Judicial de la Federación y su Gaceta XXVIII, Novena Época, Octubre de 2008. 